\title{
Comparative Study of Anti-Discrimination Laws of the UK, the United States of America and India
}

\author{
Amir Hossein Amirkahni \\ Associate Professor in Payame Nour University, Tehran \\ Reza Heydari Sheikh Tabghi
}

MA Student, Public Administration, Payame Nour, Western Tehran

\section{Doi:10.5901/mjss.2016.v7n3s2p96}

\section{Abstract}

\begin{abstract}
The issue of legal prohibition of discrimination is important because «high and positive correlation exists between the sense of political equality and belief in legitimacy of govenrment. This relationship guarantees the meaning that acceptance and confirming the legitimacy of the government realizes when the state and its Statesmen respect the principles of equality "(Yousefi, 2004). Additionally, battle against discrimination in society leads to increased participation of social groups in managing social affairs and this by itself leads to increased national cohesion and progress in the country. This paper compares the laws against discrimination in the countries of India, The Unites States of America and The United Kingdom with regards to historical and social background, sources of anti-discrimination laws, how to identify the grounds of discrimination, multiple discriminations, coverage and how to apply affirmative action.
\end{abstract}

Keywords: Discrimination, Equality, Law, United Kingdom, United States of America, India

\section{Introduction}

Discrimination means different behavior with individuals because of what they are or believe in. Discrimination aims at the heart of humanity. We all have the right to be treated equally, regardless of our race, ethnicity, nationality, class, caste, religion, belief, sex, language, sexual orientation, gender identity, age, health or other status. (Discrimination, n.d.).

Some states using their authority justify discrimination in the name of morality, religion and ideology. Even though this issue is violation of international laws, yet, issues such as limiting women's freedom are strengthened with national laws. There is simply chance for the possibility that specific groups because of what they are such as black, poor or endemic to a region are considered as criminals. At times individuals are directly because of what and how they are considered criminals such as homosexuals and at times this happens indirectly such as the condition of fluency in a specific language for employment while that job really does not need such ability in language. Equality is guarantee that every individual receives an opportunity for best use of his or her life and talents. It involves belief in the issue that nobody should have a poorer life due to place of birth, being, nature, beliefs or deficiencies. Equality acknowledges the matter that historically, specific groups of people with special traits such as race, deficiencies, sex and sexual orientation have experienced discrimination (Understanding equality, 2015).

In the view of constitutional law, equality first and foremost is the equality of individuals' rights based on a fair lawwith observance of the fundamental right of lack of intervention with other people's freedom. This is what is called the essence of freedom. When equality is viewed from the gateways of the constitutional law, emphasis is on equal rights and freedom which forms the pillars of rightfulness of the constitutional law and its fairness (Dorn, 2014). For recognition of whether a law or other governmental actions are discriminative or not, at least two methods exist. First is incorrect encountering with the principle of equality such that a law enforces inappropriate discrimination on citizens if it treats them unequally. The other method of identification of discriminatory laws is the method of their approach to the issue of freedom. Such laws allocate freedom that all people should take advantage of only to special groups (Hellman, 2013).

In this paper, we evaluated the anti-discrimination laws of the countries of India, UK and USA each of which -with consideration of historical and social conditions- have faced discrimination for centuries based on different criteria and in different forms. For this purpose, constitutional laws, legislations, some landmark judgments and other legal sources of these countries that address the issue of prohibition of discrimination will be evaluated. 


\section{Theoretical Background of the Research}

In the modern era, at least after the French revolution, equality has been one of the habitual terms used by politicians where because of its positive load it has constantly found a place in their political mottos. Equality at the same time of being simple is a dispute arising concept. Issues such as the precise meaning of equality, the relationship between equality and justice (foundations of equality), criteria of ideal equality (equality in what), perimeter of equality (equality between whom) and the position of equality in a comprehensive theory in regards with justice (value of equality) are issues that need attention when discussing this term (Equality, 2007). A law that only considers one of these aspects in practice not only does not lead to equality, but also turns discrimination into a law and doubles the problem of resolving it. Descriptive equality involves a description of equality of a common trait in two different cases such as equality of men and women when it comes to equal work. Prescriptive equality is equality in implementation of a criterion or law such as equality of individuals with respect to law (Equality, 2007).

What is important in law making for dissemination of equality and removal of discrimination is the ethical approach to equality and attention to the relationship between equality and democracy. It is deserved that attention to equality is one of its pillars. The reason is that otherwise permission for official acknowledgement of discrimination by way of other laws is indirectly issued. People's representatives who obtain the legitimacy for law making from the vote of people, based on the law of ethics, do not have the permission of creation of inappropriate discrimination between the voters and by virtue of the law of democracy should not by unequal treatment and discrimination deny part of the people from their right to participate in society, decision making and competition equal to others for achieving personal and group advantages.

Fundamental equality means that individuals are equal only in specific aspects and not in totality or they should all be treated equally. In moral equality, the basis of behavior with humans is considering equal those who have the same importance and respect. This fundamental idea of ethical equality that humans have equal respect, value and human magnanimity has been accepted as a fundamental measure in political schools and ethical cultures. Probably no political ideation exists that has neglected this approach to equality (Equality, 2007).

Equality is frequently interpreted as equal opportunity where at times it refers to equal rights and at times equal conditions of initiation (Dorn, 2014). Democratic forms of governments are those where laws are determined by people on whom the laws apply (Post, 2005). If people are to intervene in the state all people- a nation who are under the reign of one state in one politico-geographic unit called a country-should have equal share in running the country and law making and regulation on the method of implementation of the laws. If any section of the people are denied this right for any reason, not only equality but also democracy will be harmed. Therefore, respect for equality and endeavor for removal of discrimination is important for a government that claims democracy and involvement of all people in the matters of government and running the country.

\section{Legal and Social Contexts}

\subsection{The UK}

Discrimination, inequality, segregation of people in society and drawing perimeters between them has been prevalent in The UK from years ago. The Jews, even before being officially deported from England in 1290, were under vex and severely discriminated against and by force of the law of the church, a white cloth would be sewn to their clothes to be distinguished from Christians. Alongside these discriminatory traditions, presence of black people would not be tolerated in society and its history can be traced back to 1596 when black people whose ancestry was slaves from North Africa, by the order of Queen Elizabeth the first were deported. In continuation of this behavior, initially the permission for slavery and trade of slaves was issued in the Atlantic Ocean and subsequently when in 1830 slavery was abolished, slave owners were financially fined much higher compared to ex-slaves. The Aliens Act 1905, that limited entrance of Jewish people who due to being vexed in Poland and Russia immigrated to England, tried to keep Great Britain in that manner British. Additionally, the liver pool riots against black people in 1919 are examples of Britain's behavior with black people in the beginning of the twentieth century (Bam-Hutchison, 2008).

Despite a significant number, Catholics up to 1829 did not have the right to enter the parliament as a representative. Jewish people also up until 1859 were negated this right. Up until the beginning of the nineteenth century, the number of men who were executed with the verdict of homosexuality was higher than criminals. Senior citizens and individuals with deficiencies were persistently among the poorest strata of society and discrimination against them was an acceptable issue. Women-who have been more a majority than a minority in most of British history- 
objected to inequality for at least one century until finally in 1928 they obtained the right to vote equal to men. These activities in the 40's and 50's decades continued for issues such as equal pay which realized in 1955 (Thane, 2010).

In the 1950's decade, Great Britain brought in labor workers from the Caribbean basin particularly Jamaica into the country and employed them in physical occupations and labor work in the industry of transportation to rebuilt Britain after the war. With persistent growth of immigration, racial aggression also increased in cities such as London, Birmingham and Nottingham. The government began to determine a framework for immigration and up to 1972 colored people for residence in Great Britain had to either have work permit or one of their parents or grandparents had to be British residents. Up until 1970, the number of non white people resident in Britain reached 1.4 million individuals and one third were British born (Crystal, 2015).

After Britain joined the European community in 1973, new pressures were exerted for passing laws in support of equality. In 1980, the European Court issued laws that had been referred to it for multiple cases supported by the «Equal Opportunities Commission» and guaranteed equality of paycheck for groups of women which led to the ratification of a new law that prohibited gender discrimination in 1986 based upon which discrimination was acknowledged as unlawful in group contracts and expanded the domain of anti-discrimination laws to small businesses. The Commission for Equal Opportunities was formed based on the law of prohibition of gender discrimination in 1975 where this law itself was also passed under the pressure of Europe. The anti-Muslim feelings after 11 September and bombing in London in 2005 led to passing of the Racial and Religious Hatred Act in 2006 when for the first time a disrespect titled religious hatred was identified (Thane, 2010).

\subsection{India}

The caste system in India may be the oldest hierarchal system in the world that has more than 2000 years of antiquity according to research and divides society to 4 castes. These 4 castes in order of importance are Brahmins (religious leaders of India and teachers), Kshatriyas (leaders and warriors), Vaishya (merchants and traders) and Sudra (labor workers). There is also a fifth caste out of this classification that is referred to as Dalits or the untouchable (Human Rights Watch, 2001). They only have the right of performing duties that are so low and foul that no Indian belonging to a caste is willing to do (Nasiri, 2006).

Across India, especially rural regions, there are still individuals born in their caste and are occupied with trades special to it. Even if a Dalit has the ability to open a shop, a customer from higher castes will probably never touch his or her merchandise and will probably never shop there. Despite the latter, being untouchable is rarely covered by the media and it is less the topic of attention of the middle class of India.

Separate from caste distinction based on the Hindu religion, religious disputes also have important effects on the society of India. Those who gravitate to other religions from Hindu are known as Dalits. Long standing disputes between Muslims and Hindus in India in 1947 led to separation of a part of India and formation of the Islamic Republic of Pakistan.

Based on such history is how the constitutional law of India formed and removal of discrimination, enlightening perimeters of society, participation of outskirt driven in managing the country and implementation of positive initiatives are placed as foundations of work.

The constitutional law of India is one of the oldest examples of affirmative action that is referred to as «reservation». For exact implementation of this method of removal of discrimination, according to law, the community is divided into various strata. These strata are not based on the Hindu religion but on level of benefit of social strata from social facilities and harm to various strata in many years of different castes. These social strata are as follows.

- High castes, generally along history were not under oppression with regards to social issues.

- Backward classes, which are divided into four sections:

- Scheduled casts: Dalits

- Scheduled tribes: tribes that have not been absorbed into the general flow of life of the people of India and prefer to live in mountains and jungles and far from people.

- Groups that make a livelihood from crime and criminality and up until 1953 were called criminal tribes and now they are referred to as Denotified Tribes or Ex- Criminal Tribes.

- Other backward classes formed of labor workers (Sudra caste) and «untouchables» that have turned away from the Hindu religion and gravitated to other religions (Dua, n.d.).

In the constitutional law of India, in every election, a percent of the chairs are reserved for schedule castes and tribes and women. 


\subsection{The US}

The history of US from the beginning was influenced by slavery and the method of behavior with American-Africans. In fact, freedom fighting and request for civil rights has always been behind the battle with discrimination against black people and emancipation of this discrimination against black individuals in all social contexts has opened the way for removal of all other kinds of discrimination. Even though American-Africans have actively participated in all independence wars of the US, yet, when the independence declaration of was transcribed, the band that had declared slavery unacceptable was omitted under pressure by the Southerners. In 1807, the Congress prohibited import of slaves to the United States and the first legal step was taken in line with fight against slavery in the US.

In 1857, in the file of Dred Scott, the higher court ruled that there is no document at hand that the transcribers of the Declaration of Independence in the US had black people in mind when writing «all humans are created equal».

For this reason, they are not considered citizens of the United States and cannot request for a trial in Supreme Court. Additionally, the supreme court with referral to the constitutional law of the United States, where right of ownership for citizens has been recognized, issued a verdict based upon which slaves-who were property of their owners in the view of the court- even when taken to regions were slavery is prohibited, would remain slaves and their owner's property and the Federal government had no right to limit where slave owners took the slaves or not (Gunderson, 2004).

In the latter case, the Supreme Court has referred to the «Missouri Compromise» according to which the state of Missouri is considered as one of the states in which slavery is free. Yet, concurrently Maine was recognized as a free state. Additionally, according to this agreement, slavery in regions above the latitude of $36^{\circ} 30^{\prime}$ was prohibited. In that year, the Supreme Court announced this agreement against the constitutional law. Ultimately, with the end of the American civil wars in 1885 , the thirteenth amendment of the constitution of the US was ratified based upon which slavery and forceful labor was prohibited in all of the United States and regions under its legal auspices. Yet, from the same year, passing of laws titled «Black Codes» began. Black Codes were laws that were only implemented on black people.

In fact, the Southerners took advantage of the situation of the free slaves who had no place for living or capital for trade and persisted with slavery in a mild and legal form. The Black Codes invigorated a wave of complaints in Northern states and led to the fourteenth amendment in 1866 to the constitution of America-Civil Rights Act- based upon which referral was made to citizenship of African-Americans and their rights were equalized with the white people.

In 1896, in the file of «Plessy vs Ferguson», the Supreme Court did not consider the law of the state of Louisiana that made transportation companies dutiful to consider separate cabins for white and black people against amendments 13 and 14 of the constitutional law of the United States and announced that separation of individuals with different races has no disagreement with the principle of equality of humans. The principle of «separate but equal» up to 1954 and the file of «Brown vs. Board of Education» remained upheld. In this year, Supreme Court clarified that separation of black and white people in schools is a kind of inequality.

The Civil Rights Movement led by Martin Luther King in the 60's decade led to ratification of the Civil Rights act in 1964 based upon which any kind of discrimination and separation based on race, gender, skin color, religion and the like was prohibited. The seventh band of the Citizen's Law in 1964 specifies prohibition of any kind of discrimination in the mentioned cases.

\section{Sources of Anti-Discrimination Laws}

\subsection{Constitutional Laws}

The constitutional law of the UK is generally called an unwritten law. The UK does not have a codified constitutional law that can be referred to as a main law and text of reference. Yet, the latter does not mean that the UK does not have constitutional law. The constitutional law of the UK is a complex combination of contracts, principles and laws that is composed of rules, legal decisions, general laws, processes and traditions. The constitutional law of the UK is not one document but thousands of them. It is not the result of one source but many. Its transcription has not ended and is in process of evolution. It is a child of wisdom and good fortune that at times is guided by events and at times by higher decisions (Jayapalan, 2002).

A large part of the constitutional law of the UK are legislations. These are laws determining governmental procedures and method of action of governmental power. These laws are laws that form the main and fundamental topics of the constitutional law.

Examples include the description and restatement of how England, Scotland and Northern Ireland were united (Acts of Union with Scotland 1707 and with Ireland 1800), description of the relationship between the two parliaments 
(Parliament Acts 1911 and 1949) and changes that occurred in law after the UK's joining to the European Union (European Communities Act 1972, as amended), and official recognition of rights supported by the European Convention on Human Rights (Human Rights Act) and similar cases. Among these laws, there are prominent laws that were formed in confirmation of the revolution and political upheavals or emphasis on fundamental rights. The antiquity of these transcripts, their relationship with historical events and the literary value in them has given holiness to them in public thoughts and to legal scientists which is not dissimilar to a written constitutional law. These transcripts include the Magna Carta 1215, the Habeas Corpus Act 1679, the Bill of Rights 1689, Act of Settlement1701, the Act of Union with Scotland 1707 and the Statute of Westminster1931(Turpin \& Tompkins, 2011). The Human Rights Act 1998 and Equality Law 2010 can also be added to this list which is among the most comprehensive laws against discrimination.

Unlike the constitutional laws of India and United States which assign a Federal System for management of the county, the constitutional law of UK represents a centralized system. All power is in the hand of the central government and the English Parliament does what it deems necessary and the question of whether a problem is in the jurisdiction of the Federal or provincial government does not arise (Jayapalan, 2002).

Even though in the declaration of independence of the US, lack of following the law and prevention of upholding justice by George III the King of England at the time has been mentioned as the reason for this declaration by the United States, and also the constitutional law of the US (passed in 1788) considers establishment of security one of the purposes of formation of the US, yet, in the preliminary version of the constitutional law of the US, there is more emphasis on determination of the political structure of the government and the relationship between the powers with each other and also the relationship between state and central governments. In the amendments of the constitutional law citizens' rights have been addressed and 10 first amendments of the US constitutional law also titled «Bill of Rights» pertain to protection of freedom, justice and people's rights in face of the central government. The thirteenth amendment announces slavery illegal and the fourteenth clearly equally supports individuals in face of law. «Nor state shall ... deny to any person within its jurisdiction the equal protection of the law.»

The constitutional law of India in its introduction has guaranteed equality of position and opportunity for all citizens' of India. Yet, in specific articles 14 to 18 of the constitutional law of India addresses the right of equality. Based on the article 14 of the government, no one can deny the rights of «equality before law» and «equal protection of law» to any person.

« equality before law» is a negative statement that guarantees that no special favors exists for anyone. The country's law is implemented equally and no one in any situation of social position is above the law. Yet, the expression " equal protection of law» has a positive nature. It does not mean that law should be implemented equally for all people or it should be implemented unconditionally and comprehensively. The principle stated by this law is execution of law equally and without discrimination in similar conditions. This statement testifies that law should behave equally with equals and be such that in similar situations, it is to be implemented equally without discriminating against race, religion, wealth, caste or political influence (Johari, 2007). This principle forbids legislation giving advantage to one group over the other without logical reason, but leaves room for classifications.

Additionally, article fifteen prohibits discrimination in contexts of religion, race, strata, gender and birth place. It also emphasized that the mentioned cases should not create limitation and disability for individuals in access to shops, restaurants, hotels and the like as well as use of water resources, roads and public locales. The sixteenth article addresses the necessity for equal opportunity for all citizens in context related with employment or holding public office. The contexts supported by this band go beyond Articles 14 and 15 and include cases such as ethnicity and residential location. Articles 17 and 18 in order cancel and consider illegal «being untouchable» and any kind of name calling.

\subsection{International Laws}

The situation of undersigning of international conventions related to discrimination by countries is under evaluation according to the following table:

\begin{tabular}{|l|c|c|c|}
\hline Name of Convention & The US & The UK & India \\
\hline International convention of right of citizenship and political rights & $\nabla$ & $\square$ & $\square$ \\
\hline International convention on economic, social and cultural rights & $\checkmark$ & $\square$ & $\square$ \\
\hline Convention for omission of all forms of racial discrimination & $\nabla$ & $\square$ & $\square$ \\
\hline Convention for omission of all forms of discrimination against women & $\checkmark$ & $\nabla$ & $\square$ \\
\hline Convention for children's rights & $\checkmark$ & $\nabla$ & $\square$ \\
\hline Conventions for rights of disabled & $\checkmark$ & $\square$ & $\square$ \\
\hline
\end{tabular}

च: Ratified; $\checkmark$ : Signed 
Based on Article 253 of the constitutional law of India, parliament has the power to make decisions regarding implementation of any treaty with foreign countries or any decisions made in international conferences and before parliamentary ratification and internationally signed pacts are not executable. Since India has selected the common law system, its courts generally for interpretation of laws also look at judgments by other countries. Additionally, it is necessary that courts consider content and interpretations of international laws. Indian courts look at both adaptive laws and international laws to determine creative strategies for development of criteria for protecting life and freedom guaranteed in article 21 of constitutional law of India (Nehra, 2010).

The laws of the European Union have had great influence on the national laws of The UK. Treaty establishing the European Economic Community (TEEC) was signed in March 1967 in the city of Rome. Article 119 of this agreement, necessitates all member countries to stand by the principle of equal pay for men and women in return for equal work.

Five guidelines of the European Union regarding equality are: Guideline 2006/54/EC which considers equality of women and men in employment, Guideline 2010/41/EU regarding implementation of the principle of equal behavior between women and men in the self-occupation domain, Guideline 2004/113/EC regarding implementation of the principle of equal behavior with women and men with respect to access and provision of merchandise and services, Guideline 2000/43/EC regarding the principle of behaving towards individuals without attention to racial and ethnic roots and Guideline 2000/78/EC regarding establishing a general framework for equal treatment in employment and occupation (Sargeant, 2013). Every government can follow its own method and way for realizing the guidelines. With issuance of guidelines it is attempted to equalize and align quality of services and products and level of security in all member countries in the European Union.

In the US, it rarely occurs that courts refer to international agreements or even use them as help laws. When the members of the US Supreme Court use foreign laws as help laws, this reference usually faces controversial reactions. Some researchers and American activists are interested in American courts to pay more attention to votes of other courts such as Europe's Justice Court and Human Rights Court (Oppenheimer, Sources of US Equality Law, 2010).

\section{Other Laws}

\subsection{The US}

In the 60's decade, the congress of The US passed three important laws which became the basis for equality laws of the United States at the Federal level. All three laws can be related to the progress in social movement for citizens' right. The first law, Civil Rights Act 1964 was prepared during John F Kennedy's reign in reaction to the riots of Birmingham (Oppenheimer, Sources of US Equality Law, 2010). This law prohibited discrimination based on race, color, religion and national roots by private and public sectors in access to residential locations. Additionally, based on the same traits and gender, discrimination was prohibited by employers in the private section. This law also provides for the ban of discrimination based on race, color and national roots by educational institutes that have been established with governmental budget and public institutes that their budget has been provided by the Federal government. By Equal Employment Opportunity Act of 1972, an amendment was added to it that announced discrimination by public employers illegal.

The Pregnancy Discrimination Act is another amendment to the Civil Rights Act 1964 and prohibits discrimination against women due to pregnancy, maternity and medical conditions related to them. The Equal Pay Act of 1963 prohibits payment of different wages to men and women for equal work in a workshop. The Age Discrimination in Employment Act of 1967 protects individuals 40 years and older against age discrimination.

Title I of the Americans with Disabilities Act of 1990 makes it illegal to discriminate against qualified individuals with disability in the private, state and regional governmental sectors and sections 501 and 505 of the Rehabilitation Act 1972 creates this prohibition for federal employers and their contractors. Additionally, the employer should provide conditions for adaptation of physically and mentally disabled who apply for job or are among employees with the work environment unless these conditions produce unjustifiable problems for the employer. The Genetic Information Nondiscrimination Act of 2008 bans discrimination against employees and job applicants based on genetic information. Genetic information includes genetic tests of the person or one of his or her family members and also information regarding any kind of illness, disorder or condition in one of the members of the family. In all these cases revengeful action cannot be taken against the person who complains about the discrimination or participates in a legal process of complaint against discrimination.

In addition to laws passed by the congress, interpretations of the Supreme Court from the constitutional law and executive orders of the president are other sources of laws against discrimination in the United States. 


\subsection{India}

Focus of anti-discrimination laws in India is on reservation in public employment and education. In the Central Educational Institutions (Reservation in Admission) Act, 2006 organizations managed by the central government are subject to allocation of a percentage of their yearly acceptance to Scheduled tribes and other backward classes. Additionally, in the National Rural Employment Guarantee Act 2005 also reservations for classes, tribes and women can be seen.

India does not have integrated anti-discrimination law and in contexts related with equality separate acts have been passed. For example the Persons with Disabilities (Equal Opportunities, Protection of Rights and Full Participation) Act, 1995 has placed major responsibility-such as actions for prevention and early diagnosis of disability- on the government and public complexes with the purpose of guarantee of access of children with disability to free teaching in an appropriate environment up to the age of 18 years.

In 1974, the All India Institute of Medical Science (AllMS) has performed a research for identification of fetal defects in city women. In the period of one year it was shown that 7 out of 8 pregnant women who perform the test of diagnosis of the fetal gender, if the results is a girl, they decide to abort her. Therefore, as a result of complaints by the invitation of organizations defending women's rights against tests of fetal gender determination, the first national law in this regard titled the Pre-Natal Diagnostic Techniques (Prohibition of Sex Selection) Act, 1994 passed (UN Women, 2014). In this law in addition to prohibition of gender determination, laboratories, counseling centers and genetic clinics have also been limited to cases stated in the law. Additionally, to prevent any mal use, buy and sale of any imaging equipment or any other equipment by which fetal gender can be identified has been limited to specific institutes by law.

The Benefits of Maternity Act 1961 and the Equal Remuneration Act, 1976 have been passed due to existence of systematic discrimination against women in occupation.

Persons with Disabilities (Equal Opportunities, Protection of Rights and Full Participation) Act, 1995 specifies duties for the transportation sector in the direction of creation of appropriate facilities for disabled peoples' use of facilities of public transportation without discrimination. Additionally, it rules that in public buildings facilities are created such as sloped platforms for transportation of wheel chairs and signs and symbols are written in Braille hand writing.

Additionally, the government is banned from creation of discrimination based on disability in contexts related to employment. Incentives are also offered for employers who $5 \%$ of their employees are disabled individuals. This law in a closed list mentions 7 cases as disability which includes: blindness, low vision, leprosy-cured, hearing impairment, locomotor disability, mental retardation and mental illness.

In 2013, The Sexual Harassment of Women at Workplace (Prevention, Prohibition and Redressal) Act passed. In this law «sexual harassment at workplace» is descriptively and clearly defined. This definition in addition to clear abuse also covers the conditions of abuse and implicit threatening of women. Additionally, the definition presented of «abused women» presented is so broad that all women are included. The work place also goes beyond the simple relationship between employer-labor worker and includes cases such as organizations, offices, branches, units and similar to them in the private and public sectors, hospitals, educational and sport institutes and overall anywhere that the occupied person will be present during his or her work such as the transportation section. With regards to people holding jobs as well employees who are regular, case specific, temporary, day pay and even volunteers are supported under this law (Ministry of Women and Child Development, 2013).

Regarding discrimination based on religion and creed, there is no codified law; although, ban of such discrimination is emphasized in the constitutional law.

\subsection{The UK}

At the heart of the English common or private law, is what Hume called the "three fundamental laws of nature-that of the stability of possession, of its transference by consent, and of the performance of promises." Adam Smith referred to them as the "laws of justice," and F. A. Hayek termed them the "rules of just conduct." (Dorn, 2014).

The history of law making for removal of discrimination in The UK goes back to 1928 when with passing the Representation of the People (Equal Franchise) Act 1928, women were given the right to vote equally with men. In 1965 and passing the Race Relations Act was the beginning of 4 decades of passing of laws of abolishment of discrimination. The major part of these laws is as follows:

Law of Equal Pay Act 1970, Sex Discrimination Act 1975, Race Relations Act 1976, Employment Act 1989, Asylum and Immigration Appeals Act 1993, Disability Discrimination Act 1995, Protection from Harassment Act 1997, Human Rights Act 1998, National Minimum Wage Act 1998, The Maternity and Parental Leave etc. Regulations 1999, The 
Employment Equality (Sexual Orientation) Regulations 2003, The Employment Equality (Religion or Belief) Regulations 2003, Civil Partnership Act 2004, Racial and Religious Hatred Act 2006, The Employment Equality (Age) Regulations 2006, Equality Law 2006.

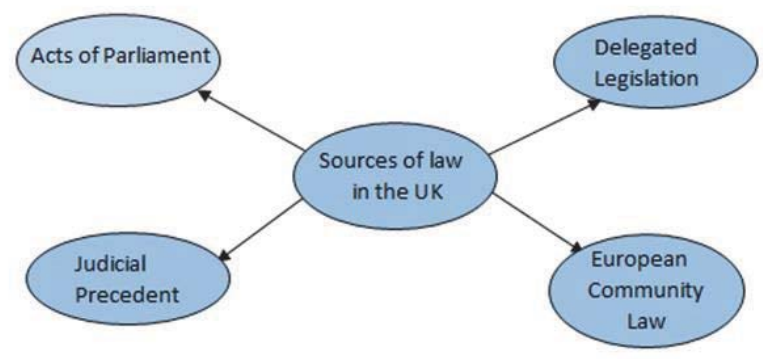

Sources of Law in The UK

Source: Motchell, 2009)

In 2010, the Equality Law 2010 was passed which collected more than 116 pieces of laws under the title of one unit. From their combination, an overall framework for protection of rights of individuals and provision of a developed context of equal opportunity for everyone has been created.

Abolishing discrimination is not just limited to the work environment and society and the law maker tries to also remove gender and religious discriminations remaining in the Monarchy's mechanism. In 2013, Succession to the Crown Act passed based upon which the priority of men to women in potential successor line of the crown gave its place to older children without attention to gender. Additionally, lack of qualification of individuals who married Catholics as potential successors was dismissed.

\section{Grounds of Discrimination and Protected Characteristics}

\subsection{Specifying Grounds}

\subsubsection{Constitutional Level}

Favourable treatment with a person and less favourable treatment with someone else necessarily does not mean discrimination. In fact, classification of individuals and considering them as members of various groups (age, sex, religion and ...) is necessary for law making and method of behavior with each. Yet, the problem is that which of these classifications and laws related to this classification is legitimate and which is not.

Courts that address issues of anti-discrimination and equal rights spend most of their time on this issue that an individual that has complained of matters related with equality should be compared to which group (Hellman, 2013).

In amendment 14 of the constitutional law of The US, it has been stated that «no state has the right to disqualify a person from equal support by the law». This statement is known as «criteria of equal support». Since the contexts of discrimination have not been identified clearly in the constitutional law, Supreme Court has the responsibility of identifying appropriate and inappropriate classification.

The American judiciary system uses three tests for this matter.

\subsubsection{Test of logical foundations or preliminary evaluation:}

This test involves a level of judiciary evaluation for determination of the adaptability of a central or state legislation with constitutional law for recognition of whether the law based on «due process» and «equal protection clause» does not violate a fundamental right or does not make a «suspect classification».

When the court reaches the conclusion that the issue is not fundamental rights and suspect classification, the considered law will be considered as constitutionally adaptive unless it is not capable to pass rational basis test. 
In this test, if the law is related to one of the important government interest, it will be confirmed by the court. Burden of proof is on the person who challenges the compatibility of the considered law with constitutional law.

Compatibility of the law with «due process» and « equal protection clause» is additionally evaluated at two other levels of «intermediate scrutiny» and «strict scrutiny» (Wex Legal Dictionary, n.d.).

\subsubsection{Intermediate scrutiny:}

Intermediate evaluation also referred to as developed or semi-suspect evaluation is a standard based on «condition of equal support» which Federal courts use for evaluation of agreement of a governmental action with the constitutional law with regards to gender or its inappropriateness. According to this standard, governmental action should be «considerably» related to an important «objective» (Hall, Ely, \& Grossman, 2005).

\subsubsection{Strict scrutiny}

In strict evaluation, the government should show that the classification challenged serves a necessary purpose and that this classification is critical for helping the purpose. This kind of evaluation is used in the following cases:

A: Suspect Classification:

Race

National Origins

Religion (based on equal protection clause or establishment clause ${ }^{1}$ )

Alienage (unless the classification falls within a recognized "political community" exception, in which case only rational basis scrutiny will be applied).

B: Classifications Burdening Fundamental Rights

Denial or Dilution of the Vote

Interstate Migration

Access to the Courts

Other Rights Recognized as Fundamental

(Levels of Scrutiny Under the Equal Protection Clause, n.d.)

In the UK unlike the US a closed list is used for determination of grounds of discrimination. ${ }^{2}$ Age, disability, gender reassignment, marriage and civil partnership, pregnancy and maternity, race, religion or belief, sex and sexual orientation are characteristics that discrimination is prohibited based upon. This law permits the government to add caste as the tenth protected characteristic to the law. Yet, the government has still not made a decision in this regard.

Yet, India uses a twofold approach in this context. First is that similar to amendment 14 of the constitutional law of the US, it uses a general statement for prohibition of any kind of discrimination (Article 14 of the constitutional law of India) and also in specification of contexts of discrimination, it uses a closed list.

Contexts such as disability, sexual orientation and age are in this Article. Under Article 15 the State shall not discriminate against any citizen on grounds only of religion, race, caste, sex, place of birth or any of them. In continuation of this article considering the historical context of India, in facing discrimination as an acute and broad problem, the prohibition of discrimination has been introduced in more detail:

No citizen shall, on grounds only of religion, race, caste, sex, place of birth or any of them, be subject to any disability, liability, restriction or condition with regard to-

(a) Access to shops, public restaurants, hotels and places of public entertainment; or

(b) The use of wells, tanks, bathing ghats, roads and places of public resort maintained wholly or partly out of State funds or dedicated to the use of the general public.

In section 2 of Article 16 also discrimination in the above grounds (in addition to descent) has been prohibited in any occupation or governmental position.

As mentioned, Article 14 of the constitutional law of India has left the way open for appropriate classifications. For a classification to pass the test of legitimacy, it should have the two following conditions:

1- Classification should be based on a clear difference such that on its basis it is possible to separate individuals or objects in a group from those outside of it.

\footnotetext{
1 The first amendment to the US constitutional law that prohibits establishment of one official religion.

2 It should not be forgotten that England does not have a codified constitutional law and a collection of some influential and all inclusive laws such as the law of equality 2010 is considered constitutional law.
} 
2- The difference mentioned should have a logical relationship with the purpose that the relevant law seeks to achieve.

Classification can be built on various bases such as geographic differences, or topics or occupations and the like. What is important is connection of the bases of classification with the objective under consideration by the law (Mishra, 2014).

\section{Other Laws}

\subsection{India}

The law making system of India has passed laws in regards to some grounds of discrimination. The Equal Remuneration Act (1976) has prohibited sex discrimination in payment for equal work. The Maternity Benefits Act (1961) and the Sexual Harassment of Women at Work Place (Prevention, Prohibition and Redressal) Act (2013) also supports women in the employment. The Persons with Disabilities (Equal Opportunities, Protection of Rights and Full Participation) Act (1995) and The Mental Health Act (1987) are allocated to the issue of disability. There is not any law about age discrimination. Regarding religious discrimination also it has been sufficed to prohibition in the constitutional law. Numerous laws also exist regarding ban of discrimination towards backward classes, tribes and other backward classes and positive discrimination in their advantage.

In regards with sexual orientation and identity, even though codified laws do not exist, yet, in 2014, India's Supreme Court in one of its landmark and influential decisions, acknowledged transgender people as a "third gender" with complete legal rights and filled in the vacuum of lack of a transcribed law in this context. Court vote stated that:

«All people deserve human rights without discrimination based on sexual orientation or identity. All people deserve «equality before law» and «equal protection of law» without any kind of discrimination based on sexual orientation and identity and possession of other human rights. Law should forbid any kind of discrimination of the kind mentioned and guarantee equal and effective legislative support for all individuals in face of such discrimination. This includes discrimination based on sexual orientation or identity, any kind of discrimination, distinction, exclusion, limitation of preference based on sexual orientation of identity which its purpose or effect is loss of effectiveness or weakening of «equality before law», «equal protection of law», being acknowledged, to have access to or implementation of all human rights and fundamental freedom-based on equality» (National Legal Services Authority vs. Union of India and others, 2012).

\subsection{The UK}

From October first, 2010, a new equality law was implemented in The UK. This law was to pass a new discrimination law in Britain to protect individuals against unfair behavior and build a society that is more just and equal and to make previous laws simpler, more standing and coordinated. Nine main laws combined with each other in the equality law of 2010 are:

- Equal Pay Act 1970

- Sex Discrimination Act 1975

- Race Relations Act 1976

- Disability Discrimination Act 1995

- The Employment Equality (Religion or Belief) Regulations 2003

- The Employment Equality (Sexual Orientation) Regulations 2003

- The Employment Equality (Age) Regulations 2006

- $\quad$ The Equality Act (Sexual Orientation) Regulations 2007

(What is the Equality Act?, 2015)

This law comprehensively defines various kinds of discrimination and protects individuals of society against discrimination due to age, disability, gender change, marriage, white marriage, pregnancy and motherhood, race, religion and faith, gender and gender orientation.

\subsection{USA}

The chapter seven of the civil rights act 1964 prohibits discrimination in occupation in the contexts of race, color, religion, 
sex or national origins.

In The Equal Pay Act 1963 also there is mention of equality of wages of women and men in return for equal work in a workshop. The law of banning discrimination based on pregnancy is an amendment to chapter 7 of the civil rights act and prohibits discrimination based on pregnancy, maternity or conditions related to one of the two. Additionally, discrimination based on disability according to the law of Americans with disability is prohibited at the level of private, state and public organizations. Additionally, discrimination based on genetic information towards an individual or his or her family is prohibited in The Genetic Information Nondiscrimination Act of 2008. The Age Discrimination in Employment Act prohibits age discrimination against individuals that are 40 years and above. Even though in the legislation by congress, there is no mention of gender orientation and identity, yet, equivalent to the executive order number 13672 , implementation of any kind of discrimination on governmental employees and contractors based on the above matters has been announced forbidden. The congress of The US has a law in process of legislation that its equivalent announces discrimination based on gender orientation and identity in the private sector also illegal. In the legislation by the congress, there is little space left for decision making by the judiciary system and characteristics supported have been clearly announced.

\section{Multiple Discriminations}

All humans have traits based on which they can be discriminated. Every human at least has an age and gender. Multiple discriminations occur when discrimination is directed to combination of at least two characteristics. For example, a black woman can be considered. The kind of discrimination they face is not like that against women or against black people, instead it is a combination of these two characteristics which has led to discrimination. It is possible that there is no discrimination against black people or women, yet, black women can be discriminated against.

For fighting against such discrimination, two approaches exist. One is evaluation of implementation of discrimination based on each characteristics. For example, asking a woman who complains about discrimination based on gender and race to prove that she has been subject of prejudice because of gender and race, because each of them is supported under distinct laws.

The second approach is intersectional approach such that combination of the characteristics considered as a new kind of discrimination and preliminary legal efforts for resolution of multiple discriminations as well as arbitrary conditions due to execution of such discrimination is provided. For example, in The US the Federal appeals court accepted that black women are under a separate group and subsequently it was accepted that any kind of combination of two traits from among characteristics of race, color, sex, national and religious origins is considered a subgroup.

Based on Article 14(1) of the Equality Act 2010 of The UK, Combined discrimination can be defined as below:

A person $(A)$ discriminates against another $(B)$ if, because of a combination of two relevant protected characteristics, A treats $B$ less favourably than A treats or would treat a person who does not share either of those characteristics.

The characteristics supported in this band are age, disability, gender reassignment, race, religion or belief, sex and sexual orientation.

In India, there is no law that addresses multiple discriminations and victims of such discrimination similar to women of the "untouchable" caste do not benefit from legal protection against intersectional discrimination.

\section{Coverage}

\subsection{Constitutional laws}

At the level of constitutional law, prohibition of discrimination more frequently covers governmental actions. Antidiscrimination laws at this level limit the government and it is the duty of the government to make laws for implementation of prohibition of discrimination by private institutes.

According to the laws of US, constitutional law is implemented only on the government, its sub branches and public institutes (Oppenheimer, Sources of US Equality Law, 2010). In the vote of the court in the Shelley v. Kraemer case it has been noted that:

"The issue emphasized in our constitutional law and in the first band of the fourteenth amendment only includes the government. The behavior of the private sector, no matter how wrong and prejudiced, is not included in this amendment. The only matter excluded from this general law is slavery.» 
In India also, similar to US, limitations of the constitutional law are directed more to the government and public institutes. Yet, Article 17 of the constitution of India cancels being untouchable «in any form» and it can also include behaviors of the private sector.

In collection of laws we know as the constitutional law of The UK, the equality act of 2010 is allocated to discrimination. Based on this law, discrimination is prohibited both in the private and governmental sections. Section eleven of the equality law 2010 mentions responsibilities of the governmental section in this regard.

- A public authority must, in the exercise of its functions, have due regard to the need to:

(a) eliminate discrimination, harassment, victimisation and any other conduct that is prohibited by or under this Act;

(b) advance equality of opportunity between persons who share a relevant protected characteristic and persons who do not share it;

(c) foster good relations between persons who share a relevant protected characteristic and persons who do not share it. ${ }^{3}$

Additionally, employers inclusive of private and public are subject to this law without consideration of this law. Hiring by way of temporary contract under titles such as educational, clerk or business partner or even without written contract will not prevent the implementation of this law on employers (Guidance for small businesses).

\subsection{Other Laws}

In US the Civil Rights Act 1964 in the context of prohibition of discrimination in access to residential locations covers both the private and public sections. Additionally, discrimination in grounds mentioned in the law is banned in teaching institutes founded with public budget and governmental units that use Federal budget. Discrimination in private workshops with more than 15 workers is also banned. Based on the amendment in 1972 to section 701 of the Civil Rights Act 1964 which is called equal opportunities act, the ban on discrimination in occupation includes public organizations as well. The Age Discrimination in Employment Act 1967 is implemented on workshops with more than 20 workers at state, private and Federal levels.

In India, Equal Remuneration Act 1976 prohibits difference in wage between women and men in any kind of governmental and nongovernmental employment. In The Benefits of Maternity Act 1961 the definition of the word employer includes both private and public sectors. A law in the context of ban of religious and other cases of discrimination in the private sector does not exist in India. Additionally, based on the opinion of the supreme court of Delhi, in the file of the NAZ foundation, Title 15(2) has banned execution of any discrimination by a «citizen to another citizen» in access to public places (Naz Foundation v Government of NCT of Delhi, 2009).

In The UK, even though the Equality Act 2010 covers private and public sectors, yet, in the time before implementation of this law, the private and public sectors were equally under consideration of the law makers. For example, the race relations act 1965 covers the public sector and part of the private sector that work for governmental institutes. The Equal Pay Act 1970 and racial discrimination act 1975, completely cover public and private sectors. It was the continuation of this trend that ultimately led to the legislation of the equality act 2010.

\subsection{Affirmative action}

Affirmative actions are cases that despite various discussions are implemented in many countries. Affirmative action includes helping return in a way groups that in time due to cultural conditions and laterality have stayed separate from society or been discriminated against and opens the way for their participation in society with removal of discrimination and other limitation. The kind of action and the group that these actions are taken against completely depend on social and historical conditions of countries. Implementation of affirmative action means acceptance of the issue that «formal equality»-equal treatment of equal people- does not by itself have the ability to create equality in society and is movement towards «substantive equality»- different treatment of different individuals.

Formal equality sees the similarities and based on it regulates its behavior and is disabled in seeing differences. In this approach, discrimination against women is to the same extent bad that discrimination against men is. This approach in legal definition has appeared as «direct discrimination». Yet, substantive equality looks at differences and instead of issuing a global verdict pays attention to the true situation of a group or individual under consideration. For example,

\footnotetext{
3 equality act 2010; part 11
} 
women more than men play the role of the nurse in the family and for «substantive equality» this issue is taken into consideration (Sergeant, 2013).

In affirmative action with a substantive equality approach, we should seek «equality of opportunity» more, not «equality of results». In other words, in the balance of «substantive equality» the scale for «equal opportunity» should be heavier than «equality of results». Otherwise, we have replaced one kind of discrimination with another kind. For example, if we rule that half of the executive committee of organizations should definitely be formed by women, even though we have resulted in equality of consequence, yet, undoubtedly this issue will prevent entrance of some qualified men to executive committees and this is discrimination. Equality of opportunity means removal of obstacles in the way of excluded groups so everyone can begin competing from one initial point.

The expression affirmative action was first used by John F Kennedy in an executive order. In that execution order, governmental contractors not only had to observe the principle of «no discrimination» in work relations, but also they had to perform an «affirmative action» for guarantee of the principle of equality of opportunity. Lyndon Johnson in defense of affirmative action states that: "You do not take a person who, for years, has been hobbled by chains and liberate him, bring him up to the starting line of a race and then say you are free to compete with all the others, and still just believe that you have been completely fair. »(Affirmative Action, n.d.). In fact, this statement looks at substantive equality with an «equal opportunity» approach not «equality of results». Equality of opportunity does not guarantee equality of results, but if performed accurately, we will be witness to increased participation of excluded groups in society.

In the United States, the focus of affirmative action is on employment and education and in relation with women, black people and national minorities. These actions include a wide range of policies. Some policies in this context are such that: targeting- not quotas- is to absorb and increase presence of women and minorities in organizations, advertising in newspapers of interest to women and minorities, evaluation of the conditions of hiring with the purpose of confidence in the issue that they are only designed based on occupational needs and among these conditions, there is no case that prevents women and minorities' from being hired.

In addition to women and minorities, people with disability also are placed in the group of individuals that should undergo affirmative action. Actions taken for this group are referred to as «reasonable accommodations». In the Americans with Disabilities Act (1990) if an employer does not provide «reasonable accommodations» for mental and physical limitations known in an employee, he or she has shown discriminative behavior unless he or she can show that implementation of such accommodations have illogical difficulty for his or her business.

Information data show need for continuation of affirmative action. For example, «National Asian Pacific American Legal Consortium» has reported that even though white people only form $48 \%$ of the educated workforce, yet they occupy $90 \%$ of high standing jobs in media, $96 \%$ executive directorship, $86 \%$ partnerships of legal firms and $85 \%$ of superintendentship of universities (Affirmative Action, n.d.).

Section 158 of the Equality Act of the UK is allocated to affirmative action. On this basis affirmative action can be applied in the following cases:

A) Individual with a supported trait (disability) has been underserved due to having this characteristic.

B) Individual with a supported trait has needs different from individuals who do not have this characteristic.

C) Participation in an activity by an individual with a supported trait is out of proportion low.

Section 13 also does not consider better treatment of disabled individuals compared to non-disabled individuals an example of direct discrimination and thus creates the possibility of affirmative action for them. In the UK similar to the US any quotas based on supported traits is prohibited and substantive equality is implemented with the equal opportunity approach not equality of consequence.

In India, though, different conditions predominate. The method of reservation for underserved groups which is illegal in other countries mentioned, has been accepted in India as the basis of the system of equality and has been placed in the constitutional law. Two groups of underserved people are included in the quota system. The first group includes caste and classified tribes that are determined by the president. ${ }^{4}$ The second group named "socially and educationally backward classes» or other «backward groups ${ }^{5} »$ which are identified by the «Backward Groups National Commission ${ }^{6} 》$.

section 5 of Article 15 of India's constitutional law provides the government with the power to take special legal initiatives for progress of any group that is socially and educationally backward to be considered for acceptance into academic institutes. Article 16 of the constitutional law also addresses equal opportunities for governmental hiring and

\footnotetext{
${ }^{4}$ Refer to Articles 341 and 342 of India's constitutional law.

${ }^{5}$ Articles 15 and 16 of India's constitutional law.

${ }^{6}$ http://ncbc.nic.in
} 
section 4 permits the government to allocate some occupations and governmental positions by way of quotas to backwards groups of society (National Commission for Backward Classes, 2014). The judge in the case of the state of Krala v N M Thomas (State Of Kerala \& Anr vs N. M. Thomas \& Ors, 1976) says in this regard:

"To my mind, this sub-Article serves not as an exception but as an emphatic statement, one mode of reconciling the claims of backward people and the opportunity for free competition the forward sections are ordinarily entitled to»"

The concept of «creamy layer» is compatible with article 15 and 16 of the constitutional law and not excluding it from affirmative action is illegal. With «layer of cream», backward groups should be treated aligned with leading groups and are not deserving of the benefits of quotas. It is evident that if «layer of cream» is not abandoned, Articles 14 and 16(1) have been violated and discrimination will happen. The reason is that with equal groups (leading groups and the cream layer of backward groups) unequal behavior has been performed (Ashoka Kumar Thakur vs Union Of India \& Ors on, 2008).

\section{Conclusion}

In all countries under consideration, discrimination based on disability, pregnancy, gender, sexual orientation, race and religion is prohibited. The method of prohibition (direct mention in laws or derived from general statements such as human magnanimity and etc) or the law related to it (constitutional law, parliamentary law, judiciary vote and ...) is subordinate to social conditions with passage of time, historical background of the country, seriousness of the decision making centers in banning discrimination and public wish.

With regards to the method of definition and identification of discrimination, use of general concepts such as human dignity and the like in the principle of prohibition of discrimination in constitutional laws and lack of use of a list that states supported traits against discrimination, the responsibility of identification of prejudice is the courts' and in case of inefficiency of the judiciary system or its adoption of a specific style of thinking, major challenges can be accompanied. An example of these tensions can be seen in the relationship of the supreme court of The US and this country's congress. From the late 70's, the development oriented policy of the US congress with regards to anti-discrimination laws faced resistance by the conservative supreme court. For example, in the case of Griggs (1971), the court initially voted that the seventh band of the law of citizenship rights 1964 covers both intentional and unintentional discrimination. Yet, in 1989, the Supreme Court reconsidered its procedure; although, in 1991, congress passed this issue in the law of citizens' rights (Oppenheimer, Congress and the Supreme Court, Conflict over Antidiscrimination Laws, 2010).

Additionally, use of open list instead of closed is a better solution for revealing the boundaries and limitations of discrimination.

In constitutional laws, generally the government is prohibited from discriminatory behavior and by way of accepting the role of the duty of omission of discrimination in society, it limits the private sector in this context and the private sector by way of other laws such as by the legislator and etc is dutiful to abolish discrimination in its work procedures. Mention of limitation of the private sector regarding discrimination in the constitutional laws is negligible.

Affirmative action is another issue that needs consideration in legislation for resolution of discrimination. In societies where based on historical conditions a part of society has been excluded from participation in the community and as a result have undergone harms economically, socially, educationally and ... and has prevented them from fair competition with other social strata, existence of affirmative action is a necessity. In this regards, a single executive prescription cannot be made. Similar to what we saw regarding the issue of affirmative action in India, the method of quotas which is illegal in other countries mentioned is acceptable for resolution of discrimination and is supported by the constitutional law and the Supreme Court.

Joining international conventions and commitment to implementing them can be one of the effective levers for progress of equality and removal of discrimination in society but it is not a guarantor of resolution of the problem of discrimination. For example, in The UK guidelines of the European Union is necessary to be implemented and should be codified in the form of national laws and passed. Yet, in The US much attention is not given to international conventions.

Votes issued by courts of other countries and international courts can also under conditions influence internal judgments. From the time of formalization of the constitutional law in India in 1950, the courts of India have periodically referred to legal decisions of other countries where the most significant of them are the UK, the US, Canada and Australia. The opinions of courts of these countries have been source of referral for rules on cases indicative of the constitutional law in the context of personal perimeter. An example is the case of the Supreme Court of India regarding the issue of illegal investigations of the police force and based on the decisions of the supreme court of The US, this 
issue was ruled violation of individual's private perimeter (Nehra, 2010). Additionally, in The UK by virtue of membership in the European Union, the decisions of European courts are binding regarding this country's internal cases.

The fact that in the constitutional and legislated laws all issues related to discrimination is predicted and attempts are made for their resolution, necessarily does not mean that we have a more just society. The reason is that in principle discrimination is an issue that forms with passage of time and it was not even imagined that one day laws would be legislated regarding discrimination based on cases such as age. The foundation of law arises from the heart of society and social, cultural, political and economic conditions of a country. What is important is changeability of laws and existence of necessary will for responding to what society wishes based on its situation.

\section{References}

Affirmative Action. (n.d.). Retrieved 10 14, 2015, from The Leadership Conference on Civil and Human Rights: http://www.civilrights.org/ resources/civilrights101/affirmaction.html (2014).

Annual Report 2013-2014. National Commission for Backward Classes. National Commission for Backward Classes. Retrieved from http://ncbc.nic.in/Writereaddata/AR\%202013-14\%20-\%20Pandey635705829394221982.pdf

Ashoka Kumar Thakur vs Union Of India \& Ors on, WP(C) No. $265 / 2006(4$ 10, 2008). Retrieved 10 14, 2015, from http://indiankanoon. org/doc/63489929/

Bam-Hutchison, J. (2008). Race, Faith, and UK Policy: a brief history. Retrieved 08 02, 2014, from University of York Website: http://www.york.ac.uk/ipup/projects/raceandfaith/discussion/bam-hutchison.html

Crystal, G. (2015, 10 09). Civil Rights in the Uk. Retrieved 10 2015, 10, from Civil Rights Movement: http://www.civilrightsmovement. co.uk/civil-rights-uk.html

Discrimination. (n.d.). Retrieved 10 10, 2015, from Amnesty International: https://www.amnesty.org/en/what-we-do/discrimination

Dorn, J. A. (2014). EQUALITY, JUSTICE, AND FREEDOM: A CONSTITUTIONAL PERSPECTIVE. CATO Journal, Vol. 34, No. 3, 492, 494.

Dua, P. (n.d.). Essay on Definition and Description of Backward Classes. Retrieved 10 10, 2015, from Share Your Essays: http://www.shareyouressays.com/86704/essay-on-definition-and-description-of-backward-classes

Equality. (2007, 06 27). Retrieved 10 10, 2015, from Stanford Encyclopedia of Philosophy: http://plato.stanford.edu/entries/equality/

Gunderson, C. (2004). The Dred Scott Decision.

Hall, K. L., Ely, J. W., \& Grossman, J. B. (Eds.). (2005). The Oxford Companion to the Supreme Court of the United States. Oxford University Press.

Hellman, D. (2013). Equality and Unconstitutional Discrimination. In D. H. Moreau, Philosophical Foundations of Discrimination Law (p. 51). Oxford: Oxford University Press.

Human Rights Watch. (2001). Caste Discrimination: A Global Concern. Human Rights Watch. Human Rights Watch. Retrieved 10 10, 2015, from http://www.hrw.org/reports/2001/globalcaste/caste0801.pdf

Jayapalan, N. (2002). Modern Governments and Constitutions (2002), Volume 1, page 35 (Vol. 1).

Johari, J. C. (2007). THE CONSTITUTION OF INDIA A Politico-Legal Study (4th ed.). Sterling Publishers Private Limited.

Levels of Scrutiny Under the Equal Protection Clause. (n.d.). Retrieved 10 14, 2015, from University of Missouri - Kansas City: http://law2.umkc.edu/faculty/projects/ttrials/conlaw/epcscrutiny.htm

Ministry of Women and Child Development-Sexual Harassment of Women at Workplace (Prevention, Prohibition and Redressal) Bill, 2013 Passed by Parliament. (2013, 02 27). Retrieved 10 13, 2015, from Press Information Bureau-Government Of India: http://pib.nic.in/newsite/erelcontent.aspx?relid=92690

Mishra, A. K. (2014). 50 Leading Cases of Supreme Court of India. discountbookstore.in.

Motchell, A. (2009). As Law (3rd ed.). Routledge-Cavendish.

National Legal Services Authority vs. Union of India and others, WP(C) 400/2012 (supreme court of india 2012). Retrieved 10 14, 2015, from http://supremecourtofindia.nic.in/outtoday/wc40012.pdf

Naz Foundation v Government of NCT of Delhi, WP(C) No.7455/2001 (High Court of Delhi 72,2009 ).

Nehra, K. S. $(2010,03)$. The Impact of Foreign Law on Domestic Judgments: India. Retrieved 1012,2015 , from Library of Congress (U.S.): http://www.loc.gov/law/help/domestic-judgment/india.php

Oppenheimer, D. B. (2010). Congress and the Supreme Court's Conflict over Antidiscrimination Law. Human Rights Magazine, 37(4). Retrieved 10 17, 2015, from http://www.americanbar.org/publications/human_rights_magazine_home/human_rights_vol37_ 2010/fall2010/congress_supreme_court_conflict_antidiscrimination_law.html

Oppenheimer, D. B. (2010, 7). Sources of US Equality Law: The View from 10,000 Meters. European Anti-discrimination Law Review (10), pp. 21,30. Retrieved 10 12, 2015, from http://ec.europa.eu/justice/discrimination/files/lawrev10_en.pdf

Rational basis test; Wex Legal Dictionary. (n.d.). Retrieved 10 14, 2015, from Cornell University Law School; Legal Information Institute: https://www.law.cornell.edu/wex/rational_basis_test

Sargeant, M. (2013). Discrimination and the Law (First ed.). Routledge.

State Of Kerala \& Anr vs N. M. Thomas \& Ors, AIR 490 (Supreme Court of India 1976). Retrieved from http://indiankanoon.org/ doc/1130169/

Thane, P. (2010, 03 01). Unequal Britain: equalities in Britain since 1945. Retrieved 10 10, 2015, from History \& Policy: 
http://www.historyandpolicy.org/policy-papers/papers/unequal-britain-equalities-in-britain-since-1945

The Equality Act: Guidance for small businesses. (n.d.). Retrieved 10 14, 2015, from Equality and Human Rights Commision: http://www.equalityhumanrights.com/sites/defaultfiles/documents/ea_legal_definitions.pdf

Turpin, C., \& Tomkins, A. (2011). British Government and the Constitution (7 ed.). Cambridge University Press.

UN Women. (2014). Sex Ratios and Gender Biased Sex Selection: History, Debates and Future Directions. UN Women. Retrieved 10 12, 2014, from http://www.in.one.un.org/img/uploads/Sex_Ratios_and_Gender_Biased_Sex_Selection_report.pdf

Understanding equality. (2015, 09 04). Retrieved $10^{-}$10, 2015 , from Equality and Human Rights Commision: http://www.equalityhumanrights.com/private-and-public-sector-guidance/education-providers/secondary-educationresources/useful-information/understanding-equality

What is the Equality Act? (2015, 10 08). Retrieved 10 14, 2015, from The Equality and Human Rights Commission: http://www.equalityhumanrights.com/legal-and-policy/key-legislatures/equality-act-2010/what-is-the-equality-act

Nasiri, M (2006). System of social strata in the Hindu tradition. Seven Skies, Summer; (30): p 105.[In Persian]

Yousefi, A (2004). Political equality and its relationship with governmental legitimacy. Iran's Social Matters; 12(44).[In Persian] 